И. В. Жерносекова, А. А. Тымчук, А. Г. Понизовцева, Н. П. Черногор, А. И. Винников

Днепропетровский нацииональный университет

\title{
БИОСИНТЕТИЧЕСКИЕ ХАРАКТЕРИСТИКИ МУТАНТНОГО ШТАММА 2P-15 В ПРИСУТСТВИИ ЭКЗОГЕННЫХ АМИНОКИСЛОТ
}

Досліджено дію екзогенних амінокислот на прояв біосинтетичної активності рифампіциностійкого штаму $2 P-15$. Показано, що амінокислоти в оптимальних концентраціях (50, 100, 200 мкг/мл) викликають максимальне збільшення синтезу білка, накопичення біомаси, активності стафілолітичних ферментів і продуктивності стрептоміцету в умовах глибинної ферментації. Всі досліджені амінокислоти забезпечили підвищення стимулювальної активності штаму в 2,0-3,7 pasa.

I. V. Zhernosekova, A. A. Tymchuk, A. G. Ponizovtseva, N. P. Chernogor, A. I. Vinnikov

Dnipropetrovsk National University

\section{BIOSINTHETICAL DESCRIPTION OF MUTANT STRAIN $2 P-15$ IN THE PRESENCE OF EXOGENOUS AMINO ACIDS}

The effect of exogenous amino acids on the biosynthetical activity of $2 P-15$ rifampycin -resistant strain was studied. Addition of the amino acids to the medium for the $2 P-15$ cultivation in the optimal concentrations $(50,100,200, \mu \mathrm{g} / \mathrm{ml})$ entailed the augmentation of a synthesis of protein, biomass, activity of staphylococcus-lytic enzymes and strain's productivity in the conditions of deep fermentation. All studied amino acids ensure the increase of stimulating activity of the mutant $2 P-15$ strain 2.0-3.7 times.

\section{Введение}

Коммерческое производство продуктов, которые синтезируются микроорганизмами в результате их жизнедеятельности, является приоритетом традиционной биотехнологии. В последнее время существенно расширился список ценных биотехнологических продуктов, с помощью которых преодолеваются продовольственные, энергетические, сырьевые и экологические проблемы. Для создания высококачественного продукта необходимо наличие высокоактивных культур микроорганизмов - продуцентов биологически активных веществ, получение которых возможно как традиционными методами селекции, пропластированием, так и методами генетической инженерии $[3 ; 6 ; 14 ; 15]$.

Известно, что для реализации высокой активности штаммов продуцентов большое значение имеют физико-химические показатели среды, источники питания, экзогенные факторы роста: аминокислоты, пурины, пиримидины, требуемые в малых количествах $[15 ; 17 ; 18]$. У многих микроорганизмов потребности в питательных веществах изучены пока недостаточно и их удается культивировать лишь на средах, содержащих сложные природные компоненты, такие как сыворотка крови, жидкость

(С) И. В. Жерносекова, А. А. Тымчук, А. Г. Понизовцева, Н. П. Черногор, А. И. Винников, 2008 78 
рубца, дрожжевой автолизат или пептоны [4; 16]. Микроорганизмы способны изменять свой обмен в соответствии с изменениями окружающей среды, что открывает возможность для управления их ростом и ферментативной активностью [3; 17].

Применение различных стимуляторов вызывает изменение метаболических процессов у микроорганизмов в сторону увеличения выхода конечного продукта, повышения окислительно-восстановительных процессов, биосинтеза белка и проницаемости клеточных мембран [17; 20]. Особого внимания заслуживают стимуляторы химической природы - ростовые факторы и предшественники синтеза макромолекул, а именно аминокислоты. Так, внесение гистидина и глутаминовой кислоты в среду культивирования грибов - продуцентов пектолитических ферментов - вызывает усиление их роста и активизацию синтеза энзимов [1]. Экзогенный метионин усиливает синтез щелочных и нейтральных экзопротеаз у Acremonium chrysogenum [13], лизин - биосинтез цефалоспорина С у C. aeramonium [26], а также пенициллина у $P$. chrysogenum [25], глутаминовая кислота повышает выход тилозина у $S$. fradiae [21]. Кроме того, аланин и цистеин усиливают в 1,5-3,0 раза рост и накопление белка в мицелии гриба Fusarium [7]. Ауксинообразование у фото- и гетеротрофных бактерий $[8 ; 10 ; 11]$ также усиливается под воздействием экзогенных аминокислот. Добавление триптофана в концентрациях 50-200 мкг/мл в среды выращивания культур Sphingomonas sp. 18, Mycobacterium sp. 1, Rhizobium sp. 5 увеличивает образование ауксина (ИУК) в 28, 30 и 34 раза, а к бактериям Rhodococcus sp. 37 и Pseudomonas sp. 24 - в 124 и 103 раза соответственно [19]. Эксперименты in vitro показали, что только некоторые бактериальные культуры могут синтезировать небольшое количество ИУК без добавления экзогенного триптофана, являющегося его метаболическим предшественником [9; 23].

Учитывая, что аминокислоты служат строительными блоками для образования основных компонентов микробных клеток - белков, а также ферментов, способствуя усилению биосинтетических процессов у многих микроорганизмов, целью данной работы было установить влияние экзогенных аминокислот на проявление биосинтетических свойств мутантного штамма стрептомицета $2 P-15$.

\section{Материал и методы исследований}

Объектом исследования был штамм стрептомицета, устойчивый к рифампицину - Streptomyces recifensis var. lyticus $2 P-15$, синтезирующий комплекс бактериолитических ферментов и стимулятор роста $[6 ; 20]$. Исследования литической активности продуцента проводили с использованием музейного штамма $S$. aureus $209 P$; стимулирующей активности - промышленного штамма $C$. tropicalis 51. Биосинтетическую активность определяли при глубинном культивировании штамма-продуцента на ферментационной среде на протяжении 72 ч при $+28^{\circ} \mathrm{C}$, в рабочем объеме среды 50 мл и частоте вращения качалки 220 об./мин. [6]. Массу мицелия стрептомицета, отфильтрованного, отмытого $5 \%$ раствором ТХУ и высушенного при $+105^{\circ} \mathrm{C}$ до постоянного веса, определяли весовым методом и выражали в мг/мл. В работе использовали аминокислоты фирмы «Реахим», которые добавляли после стерилизации до конечной концентрации 50, 100, 200 мкг/мл. Стафилолитическую активность определяли турбидиметрическим методом Isono [4] и выражали в ед./мл или ед./мг белка. Белок в пробах определяли методом Bradford [28].

При исследовании ростстимулирующей активности продуцента фильтраты культуральной жидкости (КЖ) предварительно инактивировали автоклавированием. Исследуемые растворы, разведенные 1:10, вносили в стерильную синтетическую сре- 
среду Ридера из расчета $1 \%$ от объема. Инокулятом служила суточная агаризованная культура дрожжей, приготовленная по стандарту мутности 10 . О ростстимулирующей активности штамма $2 P-15$ судили по величине прироста биомассы дрожжей в сравнении с контролем, которую выражали в \%. Накопление биомассы дрожжей оценивали оптическим методом на КФК 2 МП при 590 нм в кювете шириной 0,5 см. Стимулирующую активность рассчитывали по формуле, предложенной Н. П. Черногор [20], и выражали в ед./мл. Все эксперименты проводили в трех повторностях и обрабатывали статистически.

\section{Результаты и их обсуждение}

Синтез белка штаммом 2P-15 в присутствии треонина (табл. 1) увеличился при действии всех исследуемых концентраций, достигнув максимального показателя 156 \% к контролю. Показатели синтеза белка при минимальной (50 мкг/мл) и максимальной (200 мкг/мл) концентрации кислоты также превысили контроль, но в меньшей степени, и составили 147 и $139 \%$ соответственно. Очевидно, концентрация треонина 100 мкг/мл является оптимальной для стрептомицета, вызывая самое большое увеличение биосинтеза белка. Из данных литературы известно, что треонин не формирует аминокислотного фонда в микробной клетке, а немедленно сразу после проникновения включается в белок [2]. В присутствии ароматической аминокислоты триптофана биосинтез белка у продуцента стал выше контрольного уровня на $27 \%$ только при минимальной ее концентрации. Известно, что ароматические аминокислоты полностью в неизменном виде используются микробной клеткой на биосинтетические цели [2].

Таблица 1

Биосинтетические характеристики штамма $2 P-15$ в присутствии аминокислот

\begin{tabular}{|c|c|c|c|c|c|c|c|c|c|c|c|c|c|}
\hline \multirow{2}{*}{\multicolumn{2}{|c|}{$\begin{array}{c}\text { Концентрация, } \\
\text { мкг/мЛ }\end{array}$}} & \multicolumn{2}{|c|}{ Белок } & \multicolumn{2}{|c|}{ Биомасса } & \multicolumn{2}{|c|}{$\begin{array}{c}\text { Литическая } \\
\text { активность }\end{array}$} & \multicolumn{2}{|c|}{$\begin{array}{c}\text { Удельная } \\
\text { активность }\end{array}$} & \multicolumn{2}{|c|}{$\begin{array}{c}\text { Продуктив- } \\
\text { ность }\end{array}$} & \multicolumn{2}{|c|}{$\begin{array}{c}\text { Удельная } \\
\text { скорость } \\
\text { роста, } \mu\end{array}$} \\
\hline & & мГ/МЛ & $\begin{array}{c}\% \text { от } \\
\text { K }\end{array}$ & мГ/МЛ & $\begin{array}{c}\% \text { от } \\
\text { K }\end{array}$ & ед/мл & $\begin{array}{c}\% \text { от } \\
\text { K }\end{array}$ & ед./мг & $\begin{array}{c}\text { коэфф. } \\
\text { разл. }\end{array}$ & ед./мг & $\begin{array}{c}\% \text { от } \\
\text { K }\end{array}$ & $\mathrm{Y}^{-1}$ & $\begin{array}{c}\text { коэфф. } \\
\text { разл. }\end{array}$ \\
\hline \multicolumn{2}{|c|}{$\begin{array}{c}\text { Контроль (без } \\
\text { аминокислоты) }\end{array}$} & 0,33 & 100 & $11,5 \pm 0,06$ & 100 & $2800 \pm 148$ & 100 & 8485 & 1,0 & 243,5 & 100 & 0,16 & 1,0 \\
\hline \multirow{3}{*}{ है } & \multirow{3}{*}{$\begin{array}{c}50 \\
100 \\
200\end{array}$} & 0,421 & 127 & $11,6 \pm 0,08^{*}$ & 101 & $4000 \pm 224$ & 143 & 9501 & 1,1 & 344,8 & 141 & 0,16 & 1,0 \\
\hline & & 0,289 & 87 & $11,6 \pm 0,06^{*}$ & 101 & $3733 \pm 96$ & 133 & 12916 & 1,5 & 321,8 & 132 & 0,16 & 1,0 \\
\hline & & 0,296 & 90 & $10,0 \pm 0,10$ & 87 & $2600 \pm 132 *$ & 93 & 8783 & 1,0 & 260,0 & 107 & 0,14 & 0,9 \\
\hline \multirow{3}{*}{ 总 } & \multirow{3}{*}{$\begin{array}{c}50 \\
100 \\
200 \\
\end{array}$} & 0,484 & 147 & $10,2 \pm 0,10$ & 89 & $3733 \pm 101$ & 133 & 7713 & 0,9 & 366,0 & 150 & 0,14 & 0,9 \\
\hline & & 0,515 & 156 & $15,0 \pm 0,08$ & 130 & $3733 \pm 98$ & 133 & 7248 & 0,8 & 248,9 & 102 & 0,21 & 1,3 \\
\hline & & 0,460 & 139 & $16,6 \pm 0,12$ & 144 & $3200 \pm 82 *$ & 114 & 6956 & 0,8 & 192,8 & 79 & 0,23 & 1,4 \\
\hline \multirow{3}{*}{ 点壱 } & \multirow{3}{*}{$\begin{array}{c}50 \\
100 \\
200 \\
\end{array}$} & 0,242 & 73 & $13,2 \pm 0,05$ & 115 & $3466 \pm 86$ & 124 & 14322 & 1,7 & 262,6 & 108 & 0,18 & 1,1 \\
\hline & & 0,234 & 71 & $12,4 \pm 0,08$ & 108 & $3466 \pm 82$ & 124 & 14812 & 2,1 & 279,5 & 115 & 0,17 & 1,1 \\
\hline & & 0,265 & 80 & $24,4 \pm 0,14$ & 212 & $3200 \pm 79 *$ & 114 & 12075 & 1,4 & 131,1 & 54 & 0,34 & 2,1 \\
\hline \multirow{3}{*}{ 䆓声 } & \multirow{3}{*}{$\begin{array}{c}50 \\
100 \\
200\end{array}$} & 0,234 & 71 & $14,2 \pm 0,13$ & 123 & $4533 \pm 183$ & 162 & 19371 & 2,3 & 319,2 & 131 & 0,20 & 1,2 \\
\hline & & 0,289 & 87 & $22,6 \pm 0,10$ & 196 & $3200 \pm 96^{*}$ & 114 & 11073 & 1,3 & 141,6 & 58 & 0,31 & 1,9 \\
\hline & & 0,242 & 73 & $10,8 \pm 0,06$ & 94 & $4000 \pm 160$ & 143 & 16529 & 1,9 & 370,4 & 152 & 0,15 & 0,9 \\
\hline
\end{tabular}

Примечание: ${ }^{*}-p<0,05$.

Присутствие аминокислот (глутаминовой, аргинина) не вызвало увеличения синтеза белка у мутантного штамма $2 P-15$ ни в одной из исследуемых концентраций. Их показатели ниже контрольного уровня (колебались в пределах 71-87 \%). Это объясняется тем, что глутаминовая кислота очень быстро образует внутриклеточный пул, но он только частично расходуется для биосинтеза, а аргинин образует относи- 
тельно большой пул, который сохраняется в течение очень большого промежутка времени без каких бы то ни было изменений [2].

Все исследуемые аминокислоты обеспечили увеличение накопления биомассы штаммом на разных уровнях. Присутствие экзогенного треонина способствовало повышению биомассы на $30-44 \%$ при соответствующих концентрациях 100 200 мкг/мл. Это связано с повышением удельной скорости роста $\mu$ в 1,3 и 1,4 раза по сравнению с контролем. Глутаминовая кислота и аргинин увеличили накопление биомассы штамма до максимального значения 212 и $196 \%$ соответственно, где $\mu$ превысила контроль в 2,1 и 1,9 раза. Аминокислота триптофан не вызывала активного накопления биомассы, так как $\mu$ колебалась в пределах контрольного уровня.

Анализируя активность стафилолитических ферментов, синтезируемых продуцентом, следует отметить, что все исследуемые аминокислоты вызывают повышение активности стафилолизинов в пределах от 114 до $162 \%$. Максимальный показатель активности выявлен в присутствии аргинина в концентрации 50 мкг/мл, что и обеспечило самый высокий показатель удельной активности на уровне 19371 ед./мг. Известно, что синтез ферментов усиливается в присутствии экзогенных аминокислот, вносимых в питательную среду для культивирования плесневых грибов, вследствие непосредственного включения их в молекулу активного белка. Авторы полагают, что «аминокислоты-стимуляторы» компенсируют недостающие свободные внутриклеточные аминокислоты, необходимые для синтеза фермента [17].

Поскольку в большинстве опытов стабильные биосинтетические характеристики штамма $2 P-15$ были получены нами с использованием экзогенного треонина, представляло интерес выяснить возможность замены в среде культивирования продуцента источника азотного питания, а именно соли $\mathrm{NH}_{4} \mathrm{NO}_{3}$ на треонин в концентрации 100 мкг/мл. Из литературы известно, что аминокислоты служат вторыми по значению питательными субстратами после сахаров и являются для бактерий источниками углерода, азота и энергии [5; 16]. Замена источника азота на треонин привела к снижению всех исследуемых биосинтетических характеристик мутантного штамма $2 P-15$ (табл. 2).

Таблица 2

Биосинтетические характеристики штамма $2 P$ - 15 при замене источника азотного питания

\begin{tabular}{|c|c|c|c|c|c|c|c|c|c|c|c|c|}
\hline \multirow{2}{*}{$\begin{array}{c}\text { Вариант } \\
\text { опыта }\end{array}$} & \multicolumn{2}{|c|}{ Белок } & \multicolumn{2}{|c|}{ Биомасса } & \multicolumn{2}{|c|}{$\begin{array}{l}\text { Литическая } \\
\text { активность }\end{array}$} & \multicolumn{2}{|c|}{$\begin{array}{c}\text { Удельная } \\
\text { активность }\end{array}$} & \multicolumn{2}{|c|}{$\begin{array}{c}\text { Продуктив- } \\
\text { ность }\end{array}$} & \multicolumn{2}{|r|}{$\mu$} \\
\hline & мг/мл & $\begin{array}{c}\% \text { от } \\
\text { K }\end{array}$ & мГ/МГ & $\begin{array}{c}\% \text { oт } \\
\text { K }\end{array}$ & ед/мл & $\%$ от К & ед./мг & \begin{tabular}{|c|} 
коэфф. \\
разл.
\end{tabular} & ед./мг & $\begin{array}{c}\text { \% от } \\
\text { K }\end{array}$ & $\mathbf{u}^{-1}$ & $\begin{array}{c}\text { \% OT } \\
\text { K }\end{array}$ \\
\hline Контроль & 0,46 & 100 & $9,6 \pm 0,04$ & 100 & $2089 \pm 70,81$ & 100 & 4541 & 1,0 & 217,6 & 100 & 0,13 & 100 \\
\hline Опыт $^{\Delta}$ & \begin{tabular}{|l|}
0,104 \\
\end{tabular} & 22 & $8,58 \pm 0,03 *$ & 89 & $1044 \pm 34,66^{*}$ & 50 & 10038 & 2,2 & 122,0 & 56 & 0,12 & 92 \\
\hline
\end{tabular}

Примечание: ${ }^{\Delta}$ - среда с заменой источника азота; ${ }^{*}-p>0,05$.

Уровень белка был снижен на 78 \%, накопление биомассы стрептомицетом не превышало контрольного уровня и достигло лишь 89 \%, активность стафилолитических ферментов, лизирующих клетки стафилококка, уменьшилась в 2 раза. Наблюдалось также снижение продуктивности штамма на $44 \%$ на фоне уменьшения удельной скорости роста клеток стрептомицета на $8 \%$. Таким образом, замена источника азотного питания $\left(\mathrm{NH}_{4} \mathrm{NO}_{3}\right)$ аминокислотой треонином, которая привела к снижению всех биосинтетических параметров продуцента, нецелесообразна, так как эта среда оказалась несбалансированной по азотному питанию. Подобное изменение В. Г. Дебабов объясняет при переносе клеток с полноценной среды на минимальную, когда 
одновременно с замедлением скорости роста наблюдается резкое уменьшение синтеза стабильных типов РНК (рРНК и тРНК), при этом не возрастает активность ряда ферментов (триптофансинтетазы, гомосериндегидрогеназы, треаниндезаминазы) биосинтеза аминокислот, что очевидно, является причиной задержки роста [3].

При исследовании стимулирующей активности штамма $2 P-15$ на клетках Candida tropicalis, получено увеличение оптической плотности (ОД) клеток дрожжей при внесении КЖ в концентрации 1 \%. Максимальный прирост биомассы дрожжей $(\Delta, \%)$ в присутствии аргинина составил $282 \%$ (табл. 3 ).

Стимулирующая активность штамма $2 P-15$ на клетках Candida tropicalis

Таблица 3

\begin{tabular}{|c|c|c|c|c|c|c|c|c|c|c|}
\hline \multirow{2}{*}{$\begin{array}{c}\text { Вариант } \\
\text { опыта }\end{array}$} & \multirow{2}{*}{$\begin{array}{c}\text { Конц. } \\
\text { КЖ, } \\
\%\end{array}$} & \multicolumn{4}{|c|}{ Оптическая плотность, ОД 590 нм } & \multicolumn{2}{|c|}{$\begin{array}{c}\text { Стимулирующая } \\
\text { активность }\end{array}$} & \multirow{2}{*}{$\begin{array}{c}\text { Белок } \\
\text { мг/мл }\end{array}$} & \multicolumn{2}{|c|}{$\begin{array}{c}\text { Удельная } \\
\text { стимулирующая } \\
\text { активность }\end{array}$} \\
\hline & & $\overline{\bar{X}} \pm m$ & $\%$ от К & $\Delta \%$ & $\begin{array}{l}\text { контр. } \\
\text { КЖ, \% }\end{array}$ & ед./мл & $\%$ от K & & ед./мг & $\begin{array}{c}\text { коэфф. } \\
\text { различия }\end{array}$ \\
\hline $\begin{array}{l}\text { Контроль } \\
\text { без КЖ }\end{array}$ & 0 & $0,17 \pm 0,03$ & 100 & 0 & - & 0 & - & - & - & - \\
\hline $\begin{array}{l}\text { КЖ без } \\
\text { аминокислот }\end{array}$ & 1 & $0,30 \pm 0,08 *$ & 176 & 76 & 100 & 2530 & 100 & 0,33 & 7666 & 1,0 \\
\hline $\begin{array}{l}\text { КЖ + } \\
\text { триптофан } 50\end{array}$ & 1 & $0,43 \pm 0,10^{*}$ & 253 & 153 & 143 & 5100 & 201 & 0,42 & 12143 & 1,6 \\
\hline $\begin{array}{l}\text { КЖ + } \\
\text { треонин } 100\end{array}$ & 1 & $0,46 \pm 0,05$ & 270 & 170 & 153 & 5670 & 224 & 0,52 & 10904 & 1,4 \\
\hline $\begin{array}{l}\text { КЖ + глута- } \\
\text { миновая } \\
\text { кислота } 100\end{array}$ & 1 & $0,39 \pm 0,05$ & 229 & 129 & 130 & 4300 & 170 & 0,23 & 18696 & 2,4 \\
\hline $\begin{array}{l}\text { КЖ + } \\
\text { агринин } 100\end{array}$ & 1 & $0,65 \pm 0,03$ & 382 & 282 & 217 & 9400 & 371 & 0,29 & 32414 & 4,2 \\
\hline
\end{tabular}

Примечание: ${ }^{*}-p<0,05$.

Уровень стимулирующей активности продуцента в контроле (КЖ без аминокислоты) достиг 2530 ед./мл, в присутствии экзогенного триптофана - 5100, треонина 5670 , глутаминовой кислоты - 4300, аргинина - 9400 ед./мл. Увеличилась также удельная стимулирующая активность в $1,4-4,2$ раза по сравнению с контролем.

\section{Выводы}

Внесение экзогенных аминокислот в среду выращивания штамма $2 P-15$ положительно повлияло на биосинтетическую активность продуцента. Активно увеличился синтез белка на $56 \%$ при внесении треонина, выход биомассы стрептомицета - на $112 \%$ в присутствии глутаминовой кислоты, активность стафилолизинов - на $62 \%$ при добавлении аргинина, продуктивность штамма - на 50-52 \% в присутствии треонина и аргинина. Внесение триптофана повысило стимулирующую активность продуцента в 2,0 раза, треонина - в 2,2, глутаминовой кислоты - в 1,7, аргинина - в 3,7 раза.

\section{Библиографические ссылки}

1. Астапович Н. И. Нуклеотидный фонд и метаболизм микробной клетки. - Минск, 1979. $150 \mathrm{c}$.

2. Гершанович В. Н. Транспорт аминокислот, полипептидов и органических кислот у бактерий. - М.: Медицина, 1977. - 184 с.

3. Дебабов В. Г. Современные методы создания промышленных штаммов микроорганизмов / В. Г. Дебабов, В. А. Лившиц // Биотехнология. - М.: Высшая школа, 1988. - Т. 2. - 208 с. 
4. Джавец Э. Руководство по медицинской микробиологии / Э. Джавец, Д. А. Мельник, Э. А. Эйдельберг. - М.: Медицина, 1982. - Т. 1. - 368 с.

5. Елинов Н. П. Химическая микробиология. - М.: Высшая школа, 1989. - 448 с.

6. Жерносекова И. В. Изменчивость продуцента литических ферментов Streptomyces recifensis var. lyticus и его селекция. Дис. ... канд. биол. наук. - К., 2002. - 150 с.

7. Закордонец Л. А. Влияние аланина и цистеина на образование биологически активных веществ Fusarium sp. / Л. А. Закордонец, С. М. Супрун // Микробиол. журн. - 1983. T. 45, № 1. - С. 39-43.

8. Иванова Е. Г. Аэробные метилобактерии синтезируют ауксины / Е. Г. Иванова, Н. В. Доронина, Ю. А. Троценко // Микробиология. - 2001. - Т. 70, № 4. - С. 452-458.

9. Кравченко Л. В. Роль корневых экзометаболитов в интеграции макроорганизма с растениями. Автореф. дис. ... д-ра биол. наук. - М., 2000. - 51 с.

10. Мишке И. В. Микробные фитогормоны в растениеводстве. - Рига: Зинатне, 1988. - 151 с.

11. Мордухова Е. А. Синтез фитогормона индол-3-уксусной кислоты ризосферными бактериями рода Pseudomonas / Е. А. Мордухова, Н. П. Скворцова, В. В. Кочетков // Микробиология. - 1991. - Т. 60, № 3. - С. 494-500.

12. Муронец Е. М. Синтез индолилуксусной кислоты сапрофитной ассоциативной бактерией Agrobacterium radiobacter / Е. М. Муронец, Н. В. Белавина, Т. Н. Митронова // Микробиология. - 1997. - Т. 66, № 4. - С. 506-513.

13. Новак М. И. Регуляция биосинтеза цефалоспорина $C$ у штаммов Acremonium chrysogenum // Проблемы изыскания и биотехнологии новых антибиотиков. - Пущино, 1982. - С. 23.

14. Прист Ф. Внеклеточные ферменты микроорганизмов. - М.: Мир, 1987. - 117 с.

15. Промышленная микробиология / Под ред. Н. С. Егорова. - М.: Высшая школа, 1989. - 688 с.

16. Современная микробиология. Прокариоты / Под ред. Й. Ленгелера. - М.: Мир, 2005. T. $1 .-656 \mathrm{c}$.

17. Стимуляция жизнедеятельности микроорганизмов и вирусов / Под ред. М. Х. Шигаевой. - Алма-Ата: Наука, 1986. - 184 с.

18. Тимаков В. Д. Микробиология. - М.: Медицина, 1983. -512 с.

19. Цавкелова Е. А. Образование ауксинов бактериями, ассоциированными с корнями орхидей / Е. А. Цавкелова, Т. А. Чердынцева, А. И. Нетрусов // Микробиология. - 2005. Т. 74, № 1. - С. 55-62.

20. Чорногор Н. П. Дослідження рістстимулюючих властивостей лізоензимного препарату Streptomyces recifensis variant lyticus. Автореф. дис. ... канд. біол. наук. - К., 1998. - 20 с.

21. Штейман Б. Р. Влияние некоторых аминокислот и других соединений на биосинтез тирозина / Б. Р. Штейман, Е. А. Середенко, А. М. Макухина // Проблемы изыскания и биотехнологии новых антибиотиков. - Пущино, 1982. - С. 36-37.

22. Bradford M. M. A rapid and sensitive method for the guantitation of microgram guantities of protein utilizing the principle of protein-dye-binding // Anal. Biochem. - 1976. - Vol. 721. P. 1117-1123.

23. Fallik E. Morphology and physiology of plant roots associated with Azospirillum / E. Fallik, Y. Okon // Ed. V. Okon. - London: C. R. C. - 1994. - P. 77-86.

24. Isono M. Bacteriolytic enzyme and process for the production there of. Pat. 3649454 USA, C 12 K 1/06 / M. Isono, T. Takahashi. Y. Yamadzaki. - Pat. 1004.72.

25. Luengo J. M. Lisine regulation of penicillin biosinthesis in low producing and industrial strains of Penicillium chrisogenum / J. M. Luengo, G. Revilla // J. Gen. Microbiol. - 1979. - Vol. 115. P. 207-211.

26. Menta R. Lysine stimulation of cephalosporin $C$ synthesis in $C$. aeramonium / R. Mehta, J. L. Speth, C. H. Nach // Eur. J. Appl. Microb. and Biotech. - 1979. - Vol. 8. - P. 177-180.

Надійила до редколегії 15.04.2007 